\title{
PENGARUH KUALITAS PRODUK DAN PROMOSI TERHADAP KEPUTUSAN PEMBELIAN LENSA KACAMATA MEREK DOMAS PADA PT. DUTAMULTI INTIOPTIC PRATAMA MEDAN
}

\author{
Ina Namora Putri Siregar dan Susan \\ Universitas Prima Indonesia Medan
}

\begin{abstract}
High purchasing decisions from consumers of a product is the most important aspect for a company in doing business activity. To increase high purchases from consumers, companies should take account of the factors that influence purchasing decisions; one of them is product quality and promotion provided by the company. The purpose of this study is to examine and analyze the effect of product quality and promotion on purchasing decisions of the lens eyewear brand Domas at PT. Dutamulti Intioptic Pratama Medan. This research uses theories about product quality, promotion and purchasing decisions. This research uses quantitative approach, this type of research is descriptive quantitative and the nature of this research is explanatory. Data collection was done through interviews and questionnaires. Method of data analysis of this study is multiple linear regression. The population of this study is 100 customers who make regular purchases at PT. Dutamulti Intioptic Pratama. The results of this study show that partially the quality of calculation products showed that T-count 4,886> T-table 1.99 and promotion with T-count 8,785> T-table 1.99 have a positive and significant effect on purchasing decision. Simultaneously, the value of product quality and promotion showed F-count 72,842 > F-table 2.74 have a positive and significant effect on the lens of Domas brand eyewear at PT. Dutamulti Intioptic Pratama Medan. The conclusion of the study states that partially and simultaneously the qualities of products and promotions have a positive and significant effect on purchasing decisions of Domas eyewear lens at PT. Dutamulti Intioptic Pratama Medan.
\end{abstract}

\section{Keywords: Product Quality, Promotion, Purchase Decision}

\section{PENDAHULUAN}

Masyarakat umumnya di kota Medan lebih memilih memakai lensa kacamata sebagai alat bantu memperjelas dan mempermudah penglihatan untuk aktivitas sehari-hari dibandingkan dengan pemakaian softlens. Hal ini diakibatkan pemakaian softlens cukup rumit dan lebih ribet penggunaanya, dan juga penggunaan softlens membutuhkan perawatan lebih rumit dan biaya lebih mahal dibandingkan dengan penggunaan lensa kacamata sehingga masyarakat lebih memilih menggunakan lensa kacamata untuk sehari-hari.

Pada saat ini konsumen lebih bersifat selektif dan kritis dalam memilih produk yang akan dibeli serta tidak lagi membeli produk sekedar berdasarkan pertimbangkan dalam kegunaannya, juga termasuk segala aspek pelayanan yang melekat pada produk dan tahap pra pembelian sampai tahap purna beli. Keputusan pembelian merupakan kegiatan konsumen yang secara langsung terlihat dalam pengambilan keputusan untuk melakukan pembelian terhadap produk yang ditawarkan oleh penjual. 
Keputusan pembelian yang tinggi dari konsumen atas suatu produk merupakan aspek yang paling penting bagi suatu perusahaan dalam melakukan kegiatan bisnisnya. Untuk meningkatkan pembelian yang tinggi dari konsumen, perusahan harus memperhatikan faktor-faktor yang mempengaruhi keputusan pembelian diantaranya adalah kualitas produk dan adanya promosi yang di berikan perusahaan.

PT. Dutamulti Intioptic Pratama merupakan perusahaan yang bergerak di bidang lensa kacamata. PT. Dutamulti Intioptic Pratama juga merupakan distributor lensa kacamata di Sumatera khususnya Medan. Perusahaan ini berlokasi di Jl. Desa Serdang Ujung No.60 Tanjung Morawa Deli Serdang. Perusahaan ini memproduksi sendiri lensa kacamatanya dan langsung mendistribusi langsung ke optik optik yang menjadi pelanggan perusahaan.

PT. Dutamulti Intioptic Pratama berusaha untuk mengikuti perkembangan bisnis lensa kacamata khususnya produk single fokus, tetapi usaha yang dilakukan perusahaan tidak diikuti dengan peningkatan jumlah penjualan pada perusahaan. Sehingga target penjualan yang diberikan oleh perusahaan tidak tercapai dan tidak sesuai harapan. Yang dapat dilihat hasil wawancara dengan karyawan diketahui terjadi penurunan penjualan dari bulan Januari 2016 hingga Desember 2016. Untuk memperjelas dan mendukung permasalahan yang dihadapi PT. Dutamulti Intioptic Pratama, peneliti menggambarkan dalam tabel di bawah ini :

Tabel 1. Target dan Realisasi Jumlah Penjualan Lensa Kacamata PT Dutamulti Intioptic Pratama Januari 2016 hingga Desember 2016

\begin{tabular}{|c|l|l|l|l|c|}
\hline Tahun & \multicolumn{1}{|c|}{ Bulan } & $\begin{array}{c}\text { Target } \\
\text { (pcs) }\end{array}$ & $\begin{array}{c}\text { Realisasi } \\
\text { (pcs) }\end{array}$ & $\begin{array}{c}\text { Selisih } \\
\text { (pcs) }\end{array}$ & Persentase (\%) \\
\hline \multirow{7}{*}{2016} & Januari & 6.175 & 3.555 & $(2.620)$ & $57.57 \%$ \\
\cline { 2 - 6 } & Februari & 6.175 & 3.660 & $(2.515)$ & $59.27 \%$ \\
\cline { 2 - 6 } & Maret & 6.175 & 3.251 & $(2.924)$ & $52.64 \%$ \\
\cline { 2 - 6 } & April & 6.175 & 3.321 & $(2.854)$ & $53.78 \%$ \\
\cline { 2 - 6 } & Mei & 6.175 & 3.292 & $(2.883)$ & $53.31 \%$ \\
\cline { 2 - 6 } & Juni & 6.175 & 3.484 & $(2.691)$ & $56.42 \%$ \\
\cline { 2 - 6 } & Juli & 6.175 & 3.880 & $(2.295)$ & $62.83 \%$ \\
\cline { 2 - 6 } & Agustus & 6.175 & 3.670 & $(2.505)$ & $59.43 \%$ \\
\cline { 2 - 6 } & September & 6.175 & 3.595 & $(2.580)$ & $58.21 \%$ \\
\cline { 2 - 6 } & Oktober & 6.175 & 3.225 & $(2.950)$ & $52.22 \%$ \\
\cline { 2 - 6 } & November & 6.175 & 3.250 & $(2.925)$ & $52.63 \%$ \\
\cline { 2 - 6 } & Desember & 6.175 & 3.245 & $(3.052)$ & $52.55 \%$ \\
\hline
\end{tabular}

Berdasarkan Tabel 1 diketahui, target penjualan yang ditetapkan perusahaan bulan Januari 2016 sampai dengan bulan Desember 2016 sebesar 6.175 pcs, penjualan lensa kacamata mengalami penurunan dan tidak mampu mencapai target yang ditetapkan perusahaan. Dan rata-rata persentase penjualan sebesar $55.90 \%$ yang telah dicapai. Realisasi penjualan tertinggi pada bulan Juli 2016 sebanyak 3.880 pcs dan yang terendah terjadi pada bulan Oktober 2016 yaitu sebanyak 3.225 pcs. Hal ini menunjukan pelanggan menilai lensa kacamata itu kualitasnya kurang 
bagus sehingga terjadi penurunan penjualan.

Persaingan bisnis lensa kacamata membuat perusahaan dituntut untuk menawarkan produk yang berkualitas dan mempunyai nilai lebih, sehingga berbeda dengan produk pesaing, karena kualitas produk menjadi salah satu pertimbangan konsumen sebelum membeli suatu produk. Kualitas produk merupakan pemahaman bahwa produk yang ditawarkan oleh penjual mempunyai manfaat lebih yang tidak dimiliki oleh produk pesaing. Oleh karena itu suatu perusahaan berusaha memfokuskan pada kualitas produk dan membandingkannya dengan produk yang ditawarkan oleh perusahaan pesaing. Hal ini disebabkan faktor kualitas produk yang rendah yang ditandai dengan banyaknya retur penjualan dikarenakan Lensa kuning, lensa terlalu tebal, lensa tidak sesuai ukuran, adanya goresan pada lensa, dan coatingnya rusak, berikut data retur penjualan.

Tabel 2. Data Retur Penjualan PT. Dutamulti Intioptic Pratama Januari 2016- Desember 2016

\begin{tabular}{|c|c|c|c|c|c|}
\hline Tahun & Bulan & $\begin{array}{c}\text { Target } \\
(\mathbf{p c s})\end{array}$ & $\begin{array}{c}\text { Realisasi } \\
(\mathbf{p c s})\end{array}$ & $\begin{array}{c}\text { Selisih } \\
(\mathbf{p c s})\end{array}$ & $\begin{array}{c}\text { Persentase } \\
\mathbf{( \% )}\end{array}$ \\
\hline \multirow{6}{*}{2016} & Januari & 6.175 & 3.555 & $(2.620)$ & $57.57 \%$ \\
\cline { 2 - 6 } & Februari & 6.175 & 3.660 & $(2.515)$ & $59.27 \%$ \\
\cline { 2 - 6 } & Maret & 6.175 & 3.251 & $(2.924)$ & $52.64 \%$ \\
\cline { 2 - 6 } & April & 6.175 & 3.321 & $(2.854)$ & $53.78 \%$ \\
\cline { 2 - 6 } & Mei & 6.175 & 3.292 & $(2.883)$ & $53.31 \%$ \\
\cline { 2 - 6 } & Juni & 6.175 & 3.484 & $(2.691)$ & $56.42 \%$ \\
\cline { 2 - 6 } & Juli & 6.175 & 3.880 & $(2.295)$ & $62.83 \%$ \\
\cline { 2 - 6 } & Agustus & 6.175 & 3.670 & $(2.505)$ & $59.43 \%$ \\
\cline { 2 - 6 } & September & 6.175 & 3.595 & $(2.580)$ & $58.21 \%$ \\
\cline { 2 - 6 } & Oktober & 6.175 & 3.225 & $(2.950)$ & $52.22 \%$ \\
\cline { 2 - 6 } & November & 6.175 & 3.250 & $(2.925)$ & $52.63 \%$ \\
\cline { 2 - 6 } & Desember & 6.175 & 3.245 & $(3.052)$ & $52.55 \%$ \\
\hline
\end{tabular}

Tabel 2 di atas, menunjukkan tiap bulan terjadi retur. Dari Januari 2016 sampai Desember 2016, pada bulan Juli 2016 terjadi peningkatan retur sebesar $301 \mathrm{psc}$, dan pada bulan Mei 2016 terjadi penurunan retur sebesar 154 psc. Hal itu disebabkan oleh produk yang terjual selalu mengalami retur yang disebabkan kualitas produk yang rendah seperti lensa tebal, kuning, adanya goresan, lensa cacat, bergelombang, berkerut, $\mathrm{mc}$ rontok/rusak, berjamur serta isi diamplop tidak sesuai pesanan. Jika terjadi retur, pelanggan diperbolehkan untuk meretur barangan dengan cara potong tagihan, boleh langsung tukar ke perusahaan. Selain masalah kualitas produk, perusahaan juga mengalami permasalahan berkaitan dengan promosi. Promosi dipandang sebagai, arus informasi atau persuasi satu arah yang dibuat untuk mengarahkan seseorang atau organisasi kepada tindakan untuk menciptakan pertukaran dalam pemasaran. Jadi promosi merupakan salah satu aspek yang penting dalam manajemen pemasaran, karena promosi dapat membantu perusahaan dalam memperkenalkan produk ke pasaran. Perusahaan-perusahaan selalu mencari cara-cara untuk mendapatkan efisiensi dengan 
mengganti satu alat promosi dengan yang lain, bila keadaan ekonomisnya sudah lebih mengguntungkan. Dikarenakan akibat tingginya biaya promosi menyebabkan perusahaan jarang melakukan promosi dalam bentuk pameran maupun iklan di media cetak ataupun media massa.berikut data yang mendukung kegiatan promosi yang dilakukan perusahaan.

Tabel 3. Data Promosi Yang Dilakukan Perusahaan

\begin{tabular}{|l|l|l|}
\hline \multicolumn{1}{|c|}{ Media promosi } & \multicolumn{1}{|c|}{ Frekuensi } & \multicolumn{1}{|c|}{ Masalah } \\
\hline Personal selling & 1 x sebulan & $\begin{array}{l}\text { Hanya berkunjung ke optik besar saja, jarang } \\
\text { berkunjung ke optik kecil,sales kurang } \\
\text { memahami produk yang ditawarkan }\end{array}$ \\
\hline Advertising & $\begin{array}{l}\text { Tidak ada jangka } \\
\text { waktu }\end{array}$ & $\begin{array}{l}\text { Perusahaan hanya mengandalkan brosur } \\
\text { sampel produk,serta informasi dari sales, } \\
\text { katalog produk }\end{array}$ \\
\hline Direct marketing & $1 \mathrm{x}$ seminggu & $\begin{array}{l}\text { Kurangnya komunikasi terhadap konsumen } \\
\text { melalui telepon,pelanggan merasa kurang } \\
\text { akrab dengan marketing }\end{array}$ \\
\hline Bonus \& Hadiah & 2 sampai 3 bulan & $\begin{array}{l}\text { Bonus \& hadiah yang sudah dijanjikan tidak } \\
\text { sesuai dengan jadwal yang sudah ditentukan } \\
\text { oleh perusahaan. }\end{array}$ \\
\hline
\end{tabular}

Dari Tabel 3 diketahui

perusahaan melakukan kegiatan
promosi melalui personal selling, dan direct marketing. Permasalahannya bagian pemasaran hanya berkunjung ke optik besar saja, dan jarang berkunjung ke optik kecil, bagian pemasaran merupakan ujung tombak bagi perusahaan dalam memasarkan produknya ke pasaran, apabila bagian pemasaran kurang memahami produk yang ditawarkan maka pelanggan kurang tertarik untuk membeli produk yang ditawarkan. Dan advertising perusahaan hanya mengandalkan brosur dan sales penjualan, sedangkan permasalah direct marketing yaitu bagian pemasaran jarang melakukan komunikasi dengan pelanggan baik melalui telepon. Serta bonus dan hadiah yang seharusnya diberikan oleh perusahaan tetap waktu, tetapi perusahaan tidak melakukannya dikarenakan bonus dan hadiah harus dipesan dulu sehingga makan waktu yang cukup lama.

\section{TINJAUAN PUSTAKA}

Kualitas Produk

Menurut Kotler dan Armstrong (2008:273), "Kualitas produk adalah karakteristik produk atau jasa yang bergantung pada kemampuannya untuk memuaskan kebutuhan pelanggan yang dinyatakan atau tersirat".

Menurut Abdullah dan Tantri (2015:159), "Disini mutu produk berarti kemampuan produk untuk melaksanakan fungsinya, termasuk di dalamnya

1. Keawetan

2. Keandalan

3. Ketetapan

4. Kemudahan dipergunakan dan diperbaiki

\section{Promosi}

Menurut Stanton dalam Alma (2011:179): "Basically, promotion is an exercise in information, persuasion and conversely, a person who is persuaded is also being 
informed,"(pada dasarnya, promosi adalah latihan dalam informasi, persuasi dan sebaliknya, orang yang dibujuk juga diinformasikan)".

Laksana (2008:222), "Promosi adalah suatu komunikasi dari penjual dan pembeli yang berasal dari informasi yang tepat yang bertujuan untuk merubah sikap dan tingkat laku pembeli, yang tadinya tidak mengenal menjadi mengenal sehingga menjadi pembeli dan tetap mengingat produk tersebut".

Keberhasilan perusahaan dalam memasarkan produknya tidak terlepas dari promosi yang dilakukan perusahaan dan agar produk yang dibuat oleh perusahaan tersebut cepat mendapat perhatian dan tempat di masyarakat.

Menurut Hasan (2013 : 72), indikator promosi adalah:

1. Periklanan : tema, anggaran menurut produk, kampanye, media, frekuensi tayang, \& evaluasi

2. Pemasaran langsung : jumlah pengiriman surat, jumlah panggilan telepon

3. Selling

- Penjualan tatap muka : jumlah dan jenis penjualan, anggaran menurut wilayah, jumlah petugas, kompensasi, kuato, pelatihan, dan evaluasi

- Promosi Penjualan : anggaran menurut produk, jenis, frekuensi, evaluasi

\section{Keputusan Pembelian}

Menurut Kotler dan Amstrong (2008:181), "Keputusan pembelian konsumen adalah membeli merek yang paling disukai tetapi dua faktor bisa berada antara niat pembelian dan keputusan pembelian”.
Menurut Suparyanto dan Rosad (2015:63), “Keputusan pembelian adalahhasil evaluasi berupa keputusan tentang produk mana yang akan dibeli, dimana membelinya, kapan membelinya dan berapa banyak produk tersebut akan dibeli, serta bagaimana produk tersebut dapat dibeli".

Menurut Sunyoto (2014:283284), indikator keputusan pembelian, yaitu:

1. Keputusan tentang jenis produk Konsumen dapat mengambil keputusan pembelian suatu produk atau menggunakan uangnya untuk tujuan lain. Dalam hal ini, perusahaan harus memusatkan perhatiannya kepada orang-orang yang berminat membeli suatu produk serta alternatif lain yang mereka pertimbangkan.

2. Keputusan tentang bentuk produk.

Konsumen dapat mengambil keputusan pembelian dalam suatu produk. Keputusan tersebut menyangkut pula ukuran, mutu, corak, dan sebagainya. Dalam hal ini, perusahaan harus melakukan riset pemasaran untuk mengetahui kesukaan konsumen tentang produk yang bersangkutan agar dapat memaksimalkan daya tarik mereknya

3. Keputusan tentang merek

Konsumen harus mengambil keputusan tentang merek mana yang akan dibeli. Setiap merek memiliki perbedaan-perbedaan tersendiri. Dalam hal ini, perusahaan harus mengetahui bagaimana konsumen harus 
memilih sebuah merek dalam melakukan pembeliannya, merek yang sudah dikenal memiliki nama akan memudahkan konsumen dalam mengambil keputusannya.

4. Keputusan tentang penjualnya. Konsumen harus mengambil keputusan dimana produk tersebut akan dibeli. Dalam hal ini produsen, pedagang besar dan pengecer harus mengetahui bagaimana konsumen menyukai barang tersebut.

5. Keputusan tentang jumlah produk.

Konsumen dapat mengambil keputusan tentang seberapa banyak produk yang akan dibelinya pada suatu saat. Dalam hal ini, perusahaan harus mempersiapkan banyaknya produk sesuai dengan keinginan yang berbeda-beda dari para pembeli.

6. Keputusan tentang cara pembayaran.

Konsumen harus mengambil keputusan tentang metode atau cara pembayaran produk yang akan dibeli, secara tunai atau kredit. Keputusan tersebut akan mempengaruhi keputusan tentang tentang penjual dan jumlah pembelinya. Dalam hal ini, perusahaan harus mengetahui keinginan pembeli terhadap cara pembayarannya

Teori Pengaruh Kualitas Produk TerhadapKeputusan Pembelian

Menurut Hasan (2013:178), "Perilaku konsumen misalnya saja persepsi dan sikap terhadap kualitas produk dan kesesuaiannya terhadap diri dan keluarga mereka, memiliki dampak yang sangat besar terhadap cara mereka menilai dan mengambil keputusan untuk melakukan pembelian termasuk dalam melakukan pembelian ulang."

Teori Pengaruh Promosi Terhadap Keputusan Pembelian

Menurut Tjiptono (2008:222), "Promosi berkaitan dengan upaya untuk mengarahkan seseorang agar dapat mengenal produk perusahaan, lalu memahaminya, berubah sikap, menyukai, yakin, kemudian akhirnya membeli dan selalu ingat akan produk tersebut".

\section{METODE PENELITIAN \\ Tempat dan Waktu Penelitian}

Peneliti melaksanakan

penelitian pada PT. Dutamulti Intioptic Pratama yang beralamat di Jl. Desa Serdang Ujung No. 60 Tanjung Morawa Deli Serdang Medan serta optik-optik yang menjadi pelanggan perusahaan. Penelitian ini dilakukan dengan melakukan peninjauan langsung ke lokasi. Peneliti melakukan kegiatan penelitian pada bulan Oktober 2016 sampai dengan Maret 2017.

\section{Populasi dan Sampel}

Populasi penelitian berjumlah 100 pelanggan yang merupakan pelanggan yang melakukan pembelian rutin ke PT. Dutamulti Intioptic Pratama.

Dalam penelitian 70 pelanggan dijadikan sampel penelitian, sedangkan sisanya 30 responden digunakan untuk menguji validitas dan reliabilitas. 
Model Analisis Data Penelitian

\section{Analisis Regresi Linier Berganda}

Analisis regresi linier berganda digunakan untuk mengetahui ada tidaknya pengaruh antara variabel independen terhadap variabel dependen. Untuk menguji model tersebut maka digunakan analisa regresi linier berganda dengan rumus sebagai berikut :

$$
\mathrm{Y}=\mathrm{a}+\mathrm{b}_{1} \mathrm{X}_{1}+\mathrm{b}_{2} \mathrm{X}_{2}+\mathrm{e}
$$

\section{Koefisien Determinasi}

Menurut Ghozali (2013:97), koefisien determinasi (Adjusted $R^{2}$ ) pada intinya mengukur seberapa jauh kemampuan model dalam menerangkan variasi variabel dependen.

\section{Pengujian Hipotesis Secara Simultan (Uji- F)}

Menurut Ghozali (2013:98), ujiF statistik menunjukkan apakah semua variabel independen atau bebas yang dimasukkan dalam model mempunyai pengaruh secara bersamasama terhadap variabel dependen atau terikat.

\section{Pengujian Hipotesis Secara Parsial (Uji- t) \\ Menurut Ghozali (2013:98), menyatakan uji-t statistik menunjukkan seberapa jauh pengaruh satu variabel penjelas atau independen secara individual dalam menerangkan variasi variabel dependen.}

\section{HASIL PENELITIAN DAN PEMBAHASAN \\ Hasil Uji Analisis Regresi Linear Berganda}

Persamaan regresi dapat dilihat dari tabel hasil uji coefficients berdasarkan output SPSS terhadap variabel independen yaitu kualitas produk dan promosi dengan variabel terikat keputusan pembelian ditunjukkan pada tabel berikut:

Tabel 4. Hasil Perhitungan Regresi Berganda

\begin{tabular}{|c|c|c|c|}
\hline \multirow[b]{2}{*}{ Model } & \multicolumn{2}{|c|}{$\begin{array}{c}\text { Unstandardized } \\
\text { Coefficients }\end{array}$} & $\begin{array}{l}\text { Standardized } \\
\text { Coefficients }\end{array}$ \\
\hline & B & $\begin{array}{l}\text { Std. } \\
\text { Error }\end{array}$ & Beta \\
\hline (Constant) & 1.949 & 2.767 & \\
\hline $\begin{array}{l}\text { Kualitas } \\
\text { Produk }\end{array}$ & .495 & .101 & .355 \\
\hline Promosi & 1.217 & .139 & 639 \\
\hline
\end{tabular}

Sumber: Hasil Penelitian, Data Diolah (2017)

Pada Tabel 4 di atas yang diinterpretasikan adalah nilai dalam kolom $\mathrm{B}$, baris pertama menunjukkan konstanta (a) dan baris selanjutnya menunjukkan konstanta variabel independen. Dengan melihat tabel tersebut dapat disusun persamaan regresi linear berganda sebagai berikut:

$$
Y=1,949+0,495 X_{1}+1,217 X_{2}+e
$$

\section{Koefisien Determinasi Hipotesis}

Hasil perhitungan regresi linear berganda untuk analisis determinasi $\left(\mathrm{R}^{2}\right)$ dapat dilihat pada tabel di bawah ini:

Tabel 5. Hasil Uji Determinasi

\begin{tabular}{|l|c|r|r|c|}
\hline & & & & \\
Rodel & $\mathrm{R}$ & Adjusted & $\begin{array}{c}\text { Std. Error } \\
\text { of the } \\
\text { Square }\end{array}$ \\
R Square & Estimate \\
\hline 1 & $.827^{\mathrm{a}}$ & .684 & .674 & 2.49291 \\
\hline
\end{tabular}

Sumber: Hasil Penelitian, Data Diolah (2017)

Nilai $R$ Adjusted Square $\left(\mathrm{R}^{2}\right)$

pada Tabel 5. sebesar 0,674 atau sama dengan 67,4\%. Artinya kualitas produk dan promosi mempengaruhi keputusan pembelian sebesar 67,4\%. Sedangkan selebihnya yaitu sebesar $32,6 \%$ dipengaruhi oleh variabel lain yang tidak termasuk dalam penelitian ini seperti citra merek, atribut produk, penjualan personal, saluran distribusi, kualitas pelayanan dan lain-lain. 


\section{Pengujian \\ Hipotesis \\ Secara Simultan}

Pengujian ini dilakukan untuk mengetahui apakah variabel independen $\left(\mathrm{X}_{\mathrm{i}}\right)$ secara simultan berpengaruh signifikan terhadap variabel dependen (Y). Hasil uji simultan dapat dilihat pada Tabel 6. di bawah ini:

Tabel 6. Hasil Uji Secara Simultan (Uji F)

\begin{tabular}{|c|r|c|}
\hline Model & F & Sig. \\
\hline $\begin{array}{l}\text { Regression } \\
\text { Residual } \\
\text { Total }\end{array}$ & 72.482 & $.000^{\mathrm{a}}$ \\
\hline
\end{tabular}

Sumber: Hasil Pengolahan Data, 2017

Berdasarkan hasil perhitungan uji simultan sebagaimana terangkum dalam Tabel 6. di atas, menunjukan nilai statistik $F_{\text {hitung }}$ sebesar 72,482 dan nilai signifikan sebesar 0,000 . Selanjutnya $F_{\text {hitung }}$ dibandingkan dengan $F_{\text {tabel}}$, menurut Sugiyono (2008: 258) yang didasarkan pada $\mathrm{dk}$ pembilang $=\mathrm{k}$ dan $\mathrm{dk}$ penyebut $=(\mathrm{n}-$ $\mathrm{k}-1)$, dan taraf kesalahan yang ditetapkan 5\% maka diperoleh $\mathrm{F}_{\text {tabel }}=$ 2,74, yang berarti $F_{\text {hitung }}>F_{\text {tabel }}$. Hasil ini membuktikan bahwa secara simultan variabel kualitas produk dan promosi berpengaruh positif dan signifikan terhadap keputusan pembelian lensa kacamata. Dengan demikian, dapat disimpulkan bahwa hipotesis diterima.

\section{Pengujian Hipotesis Secara Parsial}

Uji parsial (uji t) diarahkan pada pengujian hipotesis pengaruh dari masing-masing variabel independen $\left(\mathrm{X}_{\mathrm{i}}\right)$ terhadap variabel dependen (Y). Hasil uji parsial dapat dilihat pada Tabel 7. di atas.
Tabel 7. Hasil Uji Parsial

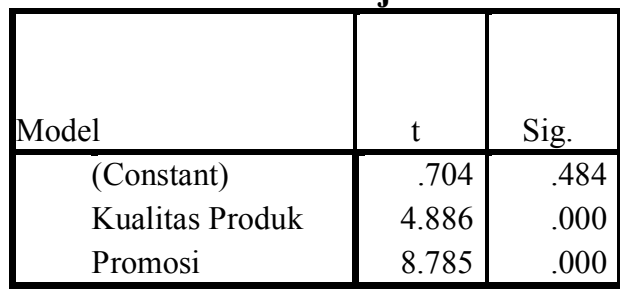

Sumber: Hasil Pengolahan Data, 2017

Berdasarkan tabel di atas dapat dijelaskan :

\section{Kualitas Produk}

Dari hasil perhitungan uji parsial kualitas produk diperoleh nilai $t_{\text {hitung }}(4,886)>t_{\text {tabel }}(1,996008)$ dengan tingkat signifikansi $(0.000)<$ (0.05). Karena nilai signifikansi lebih kecil daripada 0.05 dan nilai $t_{\text {hitung }}$ lebih besar daripada $t_{\text {tabel }}$ maka dapat disimpulkan bahwa kualitas produk berpengaruh positif dan signifikan terhadap keputusan pembelian. Sehingga hipotesis yang diajukan yaitu kualitas produk berpengaruh terhadap keputusan pembelian diterima.

Promosi

Dari hasil perhitungan uji parsial promosi diperoleh nilai $t_{\text {hitung }}$ $(8,785)>t_{\text {tabel }}(1,996008)$ dengan tingkat signifikansi $(0,000)<(0.05)$. Karena nilai signifikansi lebih kecil daripada 0.05 dan nilai $t_{\text {hitung }}$ lebih besar daripada $t_{\text {tabel }}$ maka dapat disimpulkan bahwa promosi berpengaruh positif dan signifikan terhadap keputusan pembelian sehingga hipotesis yang diajukan yaitu promosi berpengaruh terhadap keputusan pembelian diterima.

Berdasarkan hasil uji parsial terbukti yang paling dominan berpengaruh terhadap keputusan pembelian adalah variabel promosi, hal ini dibuktikan dengan hasil uji secara parsial $t$ hitung variabel 
promosi sebesar 8.785 sedangkan kualitas produk sebesar 4.886.

\section{Pembahasan Hasil Penelitian}

Pengaruh Kualitas Produk Terhadap Keputusan Pembelian

Hasil pengujian variabel kualitas produk terhadap keputusan pembelian menggunakan uji parsial $(t)$, diperoleh nilai $t_{\text {hitung }}$ kualitas produk 4,886 sedangkan nilai $t_{\text {tabel }}$ yang diperoleh sebesar 1,996008 $\left(t_{\text {hitung }}>t_{\text {tabel }}\right)$ dan tingkat signifikan pada level $0,000<0,05$ sehingga diperoleh kesimpulan hasil uji hipotesis diterima.

Hasil uji hipotesis ini sejalan dengan penelitian yang dilakukan Walukow (2014), Mongi (2013) dan Priyanto (2014) yang menyatakan kualitas produk berpengaruh positif terhadap keputusan pembelian. Hal ini menunjukkan bahwa dengan adanya kualitas produk maka keputusan pembelian akan meningkat.

Hasil penelitian ini sejalan dengan teori Abdullah dan Tantri (2015:133) "Jika kinerja produk lebih rendah daripada harapan pelanggan, pelanggan tersebut akan merasa kecewa dan sebaliknya jika melebihi harapan, pelanggan akan merasa sangat puas dan bahagia. Perasaanperasaan ini akan mempengaruhi apakah pelanggan tersebut akan membeli produk tersebut lagi dan diperkuat dengan pendapat Hasan (2013:178), "Perilaku konsumen misalnya saja persepsi dan sikap terhadap kualitas produk dan kesesuaiannya terhadap diri dan keluarga mereka, memiliki dampak yang sangat besar terhadap cara mereka menilai dan mengambil keputusan untuk melakukan pembelian termasuk dalam melakukan pembelian ulang.

Hasil jawaban responden mengenai kuesioner kualitas produk, disimpulkan dari 8 pertanyaan kualitas produk, satu pertanyaan mendukung masalah di latar belakang, sebesar 38,6\% (dijawab di nilai 2 dan 3) yaitu keandalan produk yang ditawarkan PT. Dultamulti Intioptic Pratama sudah sesuai dengan standar produk di pasaran, sedangkan 7 pertanyaan lagi tidak mendukung yaitu rata-rata 48,51\% menjawab dinilai 3 dan menganggap promosi penjualan mampu meningkatkan penjualan. Hal ini disebabkan yang menjadi responden adalah konsumen yang melakukan pembelian rutin, yang berarti adalah konsumen yang setia pada perusahaan, sehingga kualitas produk tidak menjadi permasalahan dalam keputusan pembelian.

Kesimpulan jawaban mengenai kualitas produk yaitu kualitas produk cukup baik, hal ini diketahui dari jawaban responden yang mendukung permasalahan mengenai kualitas produk hanya satu, sedangkan 7 pertanyaan lagi tidak mendukung. Pada perusahaan, meskipun kualitas produk lensa kacamata merek Domas cukup baik, disarankan untuk lebih meningkatkan kualitas produk yang sudah ada selama ini sehingga retur penjualan dengan ukuran yang tidak sesuai, Mc rusak/rontok, lensa kuning, tebal, tergores dan lain-lain dapat lebih di minimalisir.

$\begin{array}{ccr}\begin{array}{l}\text { Pengaruh } \\ \text { Keputusan }\end{array} & \begin{array}{c}\text { Promosi } \\ \text { Pembelian }\end{array} & \text { Terhadap } \\ \text { Hasil } & \text { pengujian } & \text { variabel } \\ \text { promosi } & \text { terhadap } & \text { keputusan } \\ \text { pembelian } & \text { menggunakan uji parsial }\end{array}$


$(\mathrm{t})$, diperoleh nilai $\mathrm{t}_{\text {hitung }}$ promosi 8,785 sedangkan nilai $t_{\text {tabel }}$ yang diperoleh sebesar 1,996008 $\left(t_{\text {hitung }}>t_{\text {tabel }}\right)$ dan tingkat signifikan pada level $0,000<0,05$ sehingga diperoleh kesimpulan hasil uji hipotesis diterima yaitu promosi berpengaruh terhadap keputusan pembelian. Berdasarkan hasil yang diperoleh pada penelitian ini, menunjukkan hasil yang sejalan dengan penelitian yang dilakukan Walukow (2014) dan Mongi (2013) yang menyatakan promosi berpengaruh terhadap keputusan pembelian.

Hasil penelitian ini sejalan dengan teori yang dikatakan Tjiptono (2008:222), "Promosi berkaitan dengan upaya untuk mengarahkan seseorang agar dapat mengenal produk perusahaan, lalu memahaminya, berubah sikap, menyukai, yakin, kemudian akhirnya membeli dan selalu ingat akan produk tersebut serta sejalan dengan teori Lupiyoadi dan Hamdani (2011:120), "Kegiatan promosi bukan saja berfungsi sebagai alat komunikasi antara perusahaan dengan konsumen, melainkan juga sebagai alat untuk mempengaruhi konsumen dalam kegiatan pembelian atau penggunaan jasa sesuai dengan keinginan dan kebutuhannya.

Hasil jawaban responden mengenai kuesioner mengenai promosi diketahui dua pertanyaan mendukung latar belakang masalah yaitu tenaga sales marketing PT. Dutamulti Intioptic Pratama kurang menjalin komunikasi yang baik dengan pelanggan melalui telepon dan kurang mampu menjelaskan produk ke pelanggan, sedangkan 4 pertanyaan lagi tidak mendukung yaitu rata-rata $49,28 \%$ menjawab dinilai 3 dan menganggap promosi penjualan mampu meningkatkan penjualan.

Pada perusahaan disarankan untuk melaksanakan promosi, agar konsumen lebih mengenal produk yang dipasarkan, selanjutnya melakukan pelatihan pada tenaga marketing: bagaimana cara membina hubungan baik dengan konsumen melalui telepon serta memberi pengetahuan tentang produk yang dipasarkan sehingga mampu menjelaskan lebih detail mengenai produk yang dipasarkan.

\section{PENUTUP \\ Kesimpulan}

Berdasarkan hasil analisis data dan pembahasan yang telah dikemukakan di atas, dapat diambil beberapa kesimpulan sebagai berikut:

1. Secara parsial terbukti variabel kualitas produk berpengaruh positif dan signifikan terhadap keputusan pembelian pada pada PT. Dutamulti Intioptic Pratama, terbukti dari hasil perhitungan diperoleh $t_{\text {hitung }}$ kualitas produk 4,886 sedangkan nilai tabel yang diperoleh sebesar 1,996008 $\left(\mathrm{t}_{\text {hitung }}>\mathrm{t}_{\text {tabel }}\right)$ dan tingkat signifikan pada level $0,000<$ 0,05 .

2. Secara parsial terbukti variabel promosi berpengaruh positif dan signifikan terhadap keputusan pembelian pada pada PT. Dutamulti Intioptic Pratama, terbukti dari hasil perhitungan diperoleh $t_{\text {hitung }}$ promosi 8,785 sedangkan nilai $t_{\text {tabel }}$ yang diperoleh sebesar 1,996008 $\left(t_{\text {hitung }}>t_{\text {tabel }}\right)$ dan tingkat 
signifikan pada level $0,000<$ 0,05 .

3. Secara simultan kualitas produk dan promosi berpengaruh positif dan signifikan terhadap keputusan pembelian pada PT. Dutamulti Intioptic Pratama , terbukti dari hasil perhitungan diperoleh hasil uji $F_{\text {hitung }}(72,482)$ lebih besar dibandingkan dengan $F_{\text {tabel }}(2,741574)$ dengan taraf signifikan lebih kecil dari 0,05.

\section{DAFTAR PUSTAKA}

Abdullah, Thamrin dan Tantri, Francis. 2015. Manajemen Pemasaran. Penerbit PT.RajaGrafindo Persada. Jakarta.

Alma, Buchari. 2011. Manajemen Pemasaran dan Pemasaran Jasa.Edisi Revisi. Cetakan Kesembilan. Alfabeta. Bandung.

Ghozali, Imam. 2013. Aplikasi Analisis Multivariate dengan Program SPSS, Badan Penerbit Universitas Diponegoro, Semarang.

Hasan, Ali. 2013. Marketing dan Kasus- Kasus Pilihan.Penerbit CAPS (center for Academic Publishing Service. Yogyakarta

Kotler, Philip dan Armstrong, Gary. 2008. Prinsip-Prinsip Pemasaran. Edisi 12.Jilid 1.Penerbit Erlangga. Jakarta dan Keller, Kevin Lane. 2009. Manajemen Pemasaran. Edisi 13.Jilid 1.Penerbit Erlangga. Jakarta

Laksana, Fajar. 2008. Manajemen Pemasaran; Pendekatan Praktis.Edisi Pertama.Cetakan Pertama.Graha Ilmu.Yogyakarta
Lestari, Siti. 2014.Pengaruh Kualitas Produk, Saluran Distribusi dan Strategi Pemasaran Terhadap Keputusan PembelianCV. Davindo Jaya Semarang.Jurnal Ilmiah Manajemen Kesatuan.Vol. 2 No. 1, 2014pp. 69-78.ISSN 2337 - 7860. Sekolah Tinggi Ilmu Ekonomi Kesatuan.Bogor, Indonesia

Lupiyoadi, Rambat dan Hamdani.A. 2011. Manajemen Pemasaran Jasa. Penerbit Salemba Empat. Jakarta

Mandey, Jilly Bernadette.2013. Promosi, Distribusi, Harga Pengaruhnya Terhadap Keputusan Pembelian Rokok Surya Promild.Jurnal EMBA 95.Vol.1 Hal.95-104.Fakultas Ekonomi dan Bisnis, Jurusan Manajemen Universitas Sam Ratulangi Manado.

Priyanto, Refi Eko. 2014.Pengaruh Personal Selling dan Kualitas Produk Terhadap Keputusan Pembelian. Jurnal Ilmiah Manajemen Kesatuan. Vol. 2 No. 1, 2014 pp. 69-78. ISSN 2337 - 7860. Sekolah Tinggi Ilmu Ekonomi Kesatuan.Bogor, Indonesia

Priyatno, Duwi. 2010. Mandiri BelajarAnalisis Data dengan SPSS.Cetakan Pertama. Mediakom, Yogyakarta

Sangadji, Etta Mamang dan Sopiah.2013.Perilaku

Konsumen; Pendekatan Praktis disertai Himpunan Jurnal Penelitian.Penerbit Andi. Yogyakarta

Setiadi, J. Nugroho. 2013. Perilaku Konsumen; Perspektif Kontemporer pada Motif, Tujuan, dan Keinginan 
JURNAL PLANS

Penelitian Ilmu Manajemen \& Bisnis

ISSN: $1978-7057$

E-ISSN: 2527-306X

Konsumen.

Edisi

Revisi.Penerbit

Kencana

Prenada Media Group. Jakarta

Sugiyono.2008. Metode Penelitian

Bisnis. Cetakan Kedua. CV.

Alfabeta, Bandung.

Sunyoto, Danang. 2014. Dasar-dasar

Manajemen

Pemasaran

(Konsep, Strategi dan Kasus).

Cetakan Ketiga. Penerbit CAPS

(Center of Academic Publishing

Service. Yogyakarta.

Suparyanto, RW dan Rosad. 2015.

Manajemen

Pemasaran.

Penerbit In Media. Bogor

Suryani, Tatik. 2008. Perilaku

Konsumen, Implikasi pada
Strategi Pemasaran. Edisi

Pertama. Cetakan Pertama.

Graha Ilmu. Yogyakarta

Tjiptono, Fandy. 2008. Strategi

Pemasaran. Edisi III. Penerbit

Andi. Yogyakarta

2012. Service

Management Mewujudkan

Layanan Prima. Penerbit Andi.

Yogyakarta

Sunyoto, Danang. 2014. Konsep

Dasar Riset Pemasaran \&

Perilaku Konusmen Cetakan

Kedua. Penerbit CAPS (Center

of Academic Publishing

Service. Yogyakarta. 